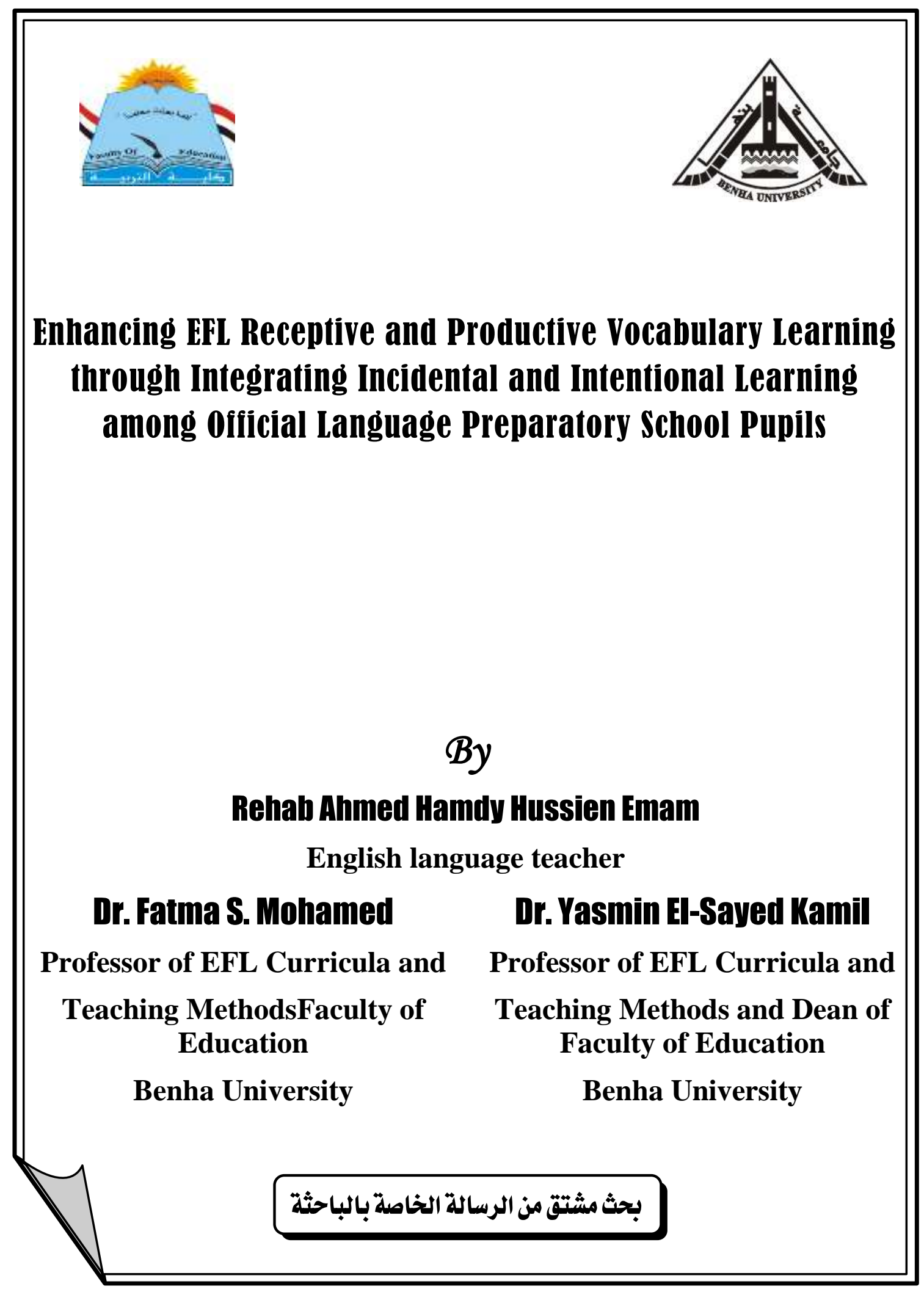




\title{
Enhancing EFL Receptive and Productive Vocabulary Learning through Integrating Incidental and Intentional Learning among Official Language Preparatory School Pupils
}

\author{
By \\ Rehab Ahmed Hamdy Hussien Emam
}

English language teacher

Dr. Fatma S. Mohamed

Professor of EFL Curricula and Teaching Methods Faculty of Education Benha University

\section{Dr. Eman M. Ahdel Haq}

Professor of EFL Curricula and Teaching Methods and Dean of Faculty of Education Benha University

\section{Dr. Mona S. Za'za}

Professor of EFL Curricula and Teaching Methods Faculty of Education Benha University

\section{Ahstract}

This study aimed at enhancing second year official language preparatory school pupils' EFL receptive and productive vocabulary learning through using the integration between incidental and intentional learning. The participants of the study were (60) second year preparatory stage pupils from Ahmed Zweil Official Language School - Benha Alqalubia. They were assigned into two groups; the experimental group $(\mathrm{N}=30)$ and the control group $(\mathrm{N}=30)$. The instruments used included a topic selection questionnaire, EFL vocabulary tests (two equivalent forms: one for pre-test and the other one for post-test). A program based on integrating incidental and intentional learning was prepared to show how to apply the integration between incidental and intentional learning. The instruments were administrated before and after the experiment. T-test was used to compare the mean scores of the control group and experimental one in the pre-post applications. Findings of the study revealed that the experimental group pupils' EFL vocabulary receptive and productive learning were higher than those of the control group pupils. Consequently, the integration between incidental and intentional learning was effective in enhancing EFL receptive and productive vocabulary learning.

Keywords: EFL receptive vocabulary learning, EFL productive vocabulary learning. Integrating incidental and intentional learning. 


\section{Introduction}

Language comprises skills and aspects. The skills are listening, speaking, reading and writing. The aspects are grammar, functions, pronunciation and vocabulary. Vocabulary involves the words that are used to transmit meaning. Vocabulary is the backbone of English language. It is a high way to recognize and to engage actively and productively in meaningful dialogue with others. It is helpful in comprehending text, and in articulating one's thoughts in written form (Sanad, 2015, Ramadan, 2016).

Nation (1994) and Al-Dagel (2009) divided vocabulary into receptive vocabulary and productive vocabulary. Receptive vocabulary refers to vocabulary that learners can recognize while reading or listening to a text. Productive vocabulary refers to vocabulary that learners can produce and use in speaking and writing to convey their thoughts. They indicated that receptive vocabulary is easier than productive vocabulary. Producing a word correctly implies correct pronunciation, spelling, using it grammatically, and linking it with other words.

Conderman, Hedin and Bresnahan (2013) summarized vocabulary importance in three points: First, Vocabulary impacts knowledge acquisition and thought development. Students who know more words have more abstract language to categorize new concepts; Second, vocabulary is highly connected to content-area success; Third, vocabulary and learning of the four English language skills are closely related.

There are various studies that were conducted to develop vocabulary learning (receptive and productive) among different groups of learners. Khodary (2007) examined the effect of a proposed non-grade activities-based program on developing English vocabulary learning (receptive and productive) for primary school pupils at Al-Irish. Results revealed that the proposed program had a positive effect on developing pupils' vocabulary learning (receptive and productive). Sulayman (2011) investigated the impact of using pictorial story style on six year primary 
school pupils' acquisition of vocabulary aspects in Mosoul. Results of the study showed that pictorial story style was effective in developing vocabulary aspects among pupils.

Ali (2014) investigated the effect of digital storytelling on developing some English vocabulary knowledge (recognition, recall, and word production) among third year preparatory pupils in Sohag. The results of the study revealed that the experimental group was much better in vocabulary production, recognition than the control group. Ramadan (2014) examined the impact of a suggested integrative reading strategy on developing preparatory pupils' oral reading fluency and vocabulary aspects at Sharkia Governorate. Results supported the impact of integrative reading strategies on developing oral reading fluency and vocabulary aspects (receptive and productive) for the participants. Zhong (2016) investigated the relationship between receptive knowledge of meaning, form, word class, collocation and association and productive knowledge through writing tasks among secondary students in China. Results showed that there were positive relationships among receptive and productive aspects which conformed that vocabulary knowledge should be seen as a network of interrelated aspects.

Gurock (2016) investigated the effectiveness of mobile learning on developing vocabulary knowledge (receptive and productive) among university students in Turkey. The study revealed that mobile learning was effective in developing both receptive and productive knowledge among university students.

In the light of the findings of the previous studies, the following conclusions can be derived:

1- Using various strategies such as pictorial story style, digital storytelling, integrative reading strategy and mobile application were effective in developing learners' EFL vocabulary learning (receptive and productive). 
2- Results of studies on the elementary stage pupils revealed the effectiveness of different interventions in developing EFL receptive and productive vocabulary such as EL-Khodary (2007) and Sulyman (2011).

3- Results of studies on the preparatory stage pupils revealed the effectiveness of different strategies in developing receptive and productive knowledge such as Ali (2014) and Ramadan (2016).

4- Few studies were conducted on secondary students. Consequently, there is a bad need for more studies for developing secondary students' receptive and productive vocabulary knowledge.

5- Few studies were conducted on university students. Consequently, there is a bad need for more studies for developing university students' receptive and productive vocabulary learning.

Nation (2000) pointed out that there are two types of vocabulary knowledge: receptive and productive vocabulary knowledge. Receptive vocabulary includes noticing the form of a word while listening or reading and retrieving its meaning. On the other hand, productive vocabulary knowledge includes the ability to express a meaning through speaking or writing and retrieving and producing the appropriate spoken or written word form. The following table Nation's presents summary of what is involved in knowing a word according to receptive and productive knowledge.

Table (1): What is involved in knowing a word?

\begin{tabular}{|c|c|c|c|}
\hline \multirow{3}{*}{ Form } & Spoken & $\begin{array}{l}\mathrm{R} \\
\mathrm{P}\end{array}$ & $\begin{array}{l}\text { What does the word sound like? } \\
\text { How is word pronounced? }\end{array}$ \\
\hline & Written & $\begin{array}{l}\mathrm{R} \\
\mathrm{P}\end{array}$ & $\begin{array}{l}\text { What does the word look like? } \\
\text { How is the word written and spelled? }\end{array}$ \\
\hline & Word Parts & $\begin{array}{l}\mathrm{R} \\
\mathrm{P}\end{array}$ & $\begin{array}{l}\text { What parts are recognizable in this word? } \\
\text { What word parts are needed to express the meaning? }\end{array}$ \\
\hline \multirow{3}{*}{ Meaning } & $\begin{array}{l}\text { Form and } \\
\text { meaning }\end{array}$ & $\begin{array}{l}\mathrm{R} \\
\mathrm{P}\end{array}$ & $\begin{array}{l}\text { What meaning does this word form signal? } \\
\text { What word form can be used to express this meaning? }\end{array}$ \\
\hline & $\begin{array}{l}\text { Concept and } \\
\text { referents }\end{array}$ & $\begin{array}{l}\mathrm{R} \\
\mathrm{P}\end{array}$ & $\begin{array}{l}\text { What is included in the concept? } \\
\text { What items can the concept refer to? }\end{array}$ \\
\hline & Associations & $\begin{array}{l}\mathrm{R} \\
\mathrm{P}\end{array}$ & $\begin{array}{l}\text { What other words does this make us think of? } \\
\text { What other words could we use instead of this one? }\end{array}$ \\
\hline \multirow{3}{*}{ Use } & $\begin{array}{l}\text { Grammatical } \\
\text { functions }\end{array}$ & $\begin{array}{l}\mathrm{R} \\
\mathrm{P}\end{array}$ & $\begin{array}{l}\text { In what patterns does the word occur? } \\
\text { In what patterns must we use this word? }\end{array}$ \\
\hline & Collocations & $\begin{array}{l}R \\
P\end{array}$ & $\begin{array}{l}\text { What words or types of words occur with this one? } \\
\text { What words or types of words must we use with this } \\
\text { one? }\end{array}$ \\
\hline & $\begin{array}{l}\text { Constraints on } \\
\text { use (register, } \\
\text { frequency....) }\end{array}$ & $\mathrm{R}$ & $\begin{array}{l}\text { Where, when, and how often would we expect to } \\
\text { meet this word? } \\
\text { Where, when and how often can we use this word? }\end{array}$ \\
\hline
\end{tabular}

Note. (Adopted from Nation, 2000: 40-41) 
Schmitt (2010) divided learning into two main approaches: a) incidental learning, and b) intentional learning. Unlike intentional learning, incidental learning is the learning without the intent to learn. It is the learning of one thing while learners' primary objective is to do something else. Hulstijan (2003) maintained that incidental and intentional learning seem similar to implicit and explicit learning. Implicit competence is incidentally acquired, is stored implicitly and is used automatically. On the other hand, he indicated that explicit learning involves awareness at the time of learning.

Incidental vocabulary learning is a by-product learning approach as the learners learn vocabulary while involve in another task such as reading or listening. It is learning without intend to learn. Nation (2000) assured that learners learn many vocabularies incidentally through extensive reading as through reading vocabulary incidentally occurs with the learner guessing the meaning of unknown words using context clues and other context strategies such as retrieval. Incidental vocabulary learning can be a useful approach for all language learners at all levels.

Kerka (2000), Ellis (2008) and Barker (2012) characterized incidental learning as unintentional, unsystematic, informal, indirect, situated, contextual, social, and ubiquitous foundational cognitive ability thought to support diverse complex functions. Incidental learning happens in many ways: through repetition, social interaction, problem solving, from being forced to accept or adapt to situations, or from implicit meaning in classroom.

Huckin and coady (1999) mentioned many advantages of incidental vocabulary learning as follows: first, it is contextualized, gives the learner a rich sense of word use and meaning.Second, it is pedagogically efficient in that it yields two activities at the same time, vocabulary learning and reading, and it is more learners - based approach. 
However, learning vocabulary incidentally through reading in context fosters an elaborate processing of words and facilitates its retention in memory. Guessing from context is a complex and often difficult strategy to carry out successfully as many linguists put it(Beltran, Contesse \& Lopez, 2010). Nation (2013) added that for fast vocabulary expansion, there is a need to accompany it with intentional learning. Moreover Schmitt (2007) suggested that contextualized learning through reading is effective but contextualized reading plus explicit instruction is superior.

The other way of learning vocabulary is through intentional vocabulary approach. Schmitt (2010) indicated that in this approach words are explicitly taught and intentionally focused upon by the learner through learning methods such as key word method. Hulstijn $(2001,289)$ defined intentional vocabulary learning as any activity that aims at committing lexical information to memory deliberately. Sokmen (1997) added that the main strategies of intentional learning are mnemonic, word formation and semantic map strategy.

Schmitt (2010), Beltran, Contesse \& Lopez (2010) and Nation (2013) concluded that intentional and incidental learning approaches have different advantages and disadvantages. Intentional vocabulary learning leads to more robust and faster learning and focuses on important vocabulary selected by the teacher as high frequency and targeted words. Incidental learning is slow and untargeted. It is an error prone process. On the other hand, incidental learning can address words which cannot be explicitly taught for time reasons; fills out the kinds of contextual words knowledge which cannot easily be explicitly taught; involves deeper engagement leading to better retention, provides recycling for words already taught and vocabulary learning occurs while improving other language skill areas as reading. It can occur when one is using language for communicative purposes and so gives a double benefit for time expended. 
Scott (2012) assured that intentional and incidental learning approaches are complementary and not opposites. Schmitt (2000) agreed with Scott's view and indicated that both the two approaches are necessary and that a well designed learning program should involve a balance between the two approaches, with opportunities for incidental learning taking up the majority of the balance.

Some studies were conducted on the effect of integrating incidental and intentional learning for developing EFL vocabulary learning: e.g., Yanmei (2013), Al-Darayseh (2014) and Sok (2017).

Yanmei's (2013) study investigated the effect of incidental vocabulary learning through reading, intentional vocabulary learning and the combination between incidental and intentional vocabulary learning on Freshmen' students vocabulary learning at Shandong University of Finance and Economics. The results revealed that intentional instruction was significantly better than incidental learning in vocabulary learning but the combination of incidental and intentional was the superior learning.

Al-Darayseh (2014) examined the impact of a combination of both explicit (intentional) and implicit (incidental) on developing university students' vocabulary learning and reading comprehension at Al-Imam University. The findings revealed that the combination of explicit (intentional) and implicit (incidental) vocabulary strategies had proved to be effective in developing students' vocabulary learning and reading comprehension. Sok (2017) investigated the effect of four learning conditions (incidental learning, intentional learning, distributed incidental learning and combined incidental and intentional learning) on vocabulary learning among University students in New York. The results showed that there was no significant difference between incidental and intentional learning on vocabulary learning, while the combination between incidental and intentional learning led to the most substantial vocabulary learning. 
In the light of the findings of the previous studies, the following conclusions can be derived:

1- Using the integration between incidental and intentional learning was better than incidental only or intentional only for developing EFL vocabulary learning.

2- There is a need for using integration between incidental and intentional learning for developing EFL vocabulary learning among preparatory stage pupils.

\section{Context of the problem}

In spite of the importance of vocabulary learning in English language learning, there is a lack in the pupils' EFL vocabulary learning. This lack is resulted fromthe fact that students don't have the opportunity to practice vocabulary in a communicative context. They make mistakes in pronunciation. They lack the ability to comprehend what they read. They couldn't communicate their ideas as they would like to and they could hardly grasp the ideas transmitted to them Because of their weak vocabulary (ElGarawany, 2010). Students need to learn vocabulary in meaningful context and realistic situations not only see the form but also hear the pronunciation and practice the words in context (El- Khodary, 2007; El-Garhy, 2013 \& Ali, 2014). Using context skills is the most frequent way to discover and learn the meaning of a new word (Hamed, 2009).

The vocabulary learning received a scanty focus as the priority has been given to structures. In the class, vocabulary is taught as a list of words usually arranged alphabetically and defined. This implies that teaching vocabulary means teaching of words. This raises some conclusions: the word may be understood but not used, the word may not actually be understood but may be used, the idea to which a 'word' is applied may be known but the symbol neither known nor usedand the word by itself may mean little or nothing and only the meaning of a 'word' may be known or used (Al-Dagel, 2009). 
To document the problem, a pilot study was conducted to investigate the problem of EFL learning vocabulary learning among2nd year official preparatory school pupils $(\mathrm{N}=26)$ at Hassan Abu Baker official school, ElQanter Elkhyria, Alqluabia Governorate on Thursday March, $1^{\text {st }}$, 2015.The results of the vocabulary test indicated pupils' low level in vocabulary learning as most of the pupils can't achieve $60 \%$ of the test.

\section{Statement of the problem $\square$}

The problem of the present study lies in the low level of EFL vocabulary learning (receptive and productive) among second year official language preparatory school pupils. This study was an attempt to enhance EFL receptive and productive vocabulary learning through using the integration between incidental and intentional learning among second - year official language preparatory school pupils. To investigate this problem, the researcher attempted to answer the following questions:

1- What are the EFL receptive vocabulary aspects required for $2^{\text {nd }}$ year official language preparatory school pupils?

2- What are the EFL productive vocabulary aspects required for $2^{\text {nd }}$ year official language preparatory school pupils?

3- What are the features and bases of the program based on the integration between incidental and intentional learning for developing EFL receptive and productive vocabulary learning?

4- What is the effect of the program based on the integration between incidental and intentional learning on developing EFL receptive vocabulary learning among second year official language preparatory school pupils?

5- What is the effect of the program based on the integration between incidental and intentional learning on developing EFL productive vocabulary learning among second year official language preparatory school pupils? 


\section{Hypotheses of the study}

In the light of the previous literature and related studies, the following hypotheses were formulated:

1- There is a statistically significant difference between the mean scores of the experimental group and the control one in the post assessment of receptive vocabulary aspects in favor of the experimental group.

2- There is a statistically significant difference between the mean scores of the experimental group and the control one in the post assessment of the productive vocabulary aspects in favor of the experimental group.

\section{Delimitations of the Study}

This study was delimited to:

1- A sample of second year official language preparatory school pupils at Ahmed Zewail Official Language School, Benha, Alqluabia Governorate.

2- Some EFL receptive vocabulary aspects and some EFL productive vocabulary aspects required for second year official language preparatory school pupils.

\section{Method of the study}

\section{Design of the study}

The present study utilized the quasi-experimental design, known as pre - posttest Experimental and Control group Design. The experimental group was taught using the integration of the incidental and intentional learning, while the control group was taught using the regular method.

\section{Participants of the study $\square$}

Participants in the present study were 60 pupils comprising two intact classes from 2nd year preparatory school pupils at Ahmed Zweil Official Language School, Benha, Alqalubia Governorate during the first term of the school year 2018-2019. Class 2/A served as the experimental group $(n=30)$ while, class $2 / B$ served as a control group $(n=30)$. 


\section{Instruments and Materials of the Study}

- A topic selection questionnaire.

- EFL vocabulary tests (two equivalent forms: one for pre-testing and the other one for post-testing).

- The program based on the integration between incidental and intentional learning.

\section{Topic Selection Questionnaire}

The topic selection questionnaire was used to identify the topics that were selected by the pupils according to their interest to develop their learning in extensive reading (Nation, 2000).

\section{Description of the EFL vocabulary test (receptive and productive)}

The EFL vocabulary learning tests were designed to measure two main aspects, receptive and productive which involved: five receptive and five productive aspects. The passages in the test were selected from Beyond Words by Maley and Duff (1986), and The British Council Site. The total score of the test was 68 (32 scores for receptive aspect questions and 36 scores for productive aspect questions). One markwas given for each correct answer; zero is given to wrong answer or left questions.

For validity purpose, two methods were used: face validity and internal consistency. For face validity purpose, the EFL vocabulary tests (receptive and productive) were submitted to a panel of jury members of EFL specialists in faculties of education $(n=11)$ and experts in the field of teaching and supervisors $(n=4)$.They were asked to state their opinions regarding the clarity of the test instructions, the difficulty level and length of the test, and how far each item measures the aspect intended to measure. Most of the jury members accepted the test as it was suggesting that it does not need any modifications either by adding or omitting any of the test items. However, few jury members suggested simplifying question four, simplifying the passage in question two on the post test and omitting one semantic map. The test was modified according to the jury members' opinions. 
For estimating internal consistency of the test, correlation coefficient between the total score of each aspect (receptive aspects and productive aspects) and the total score of the test was calculated.

Table (2) Pearson correlations between each aspect of the test and the total score of the test

\begin{tabular}{|c|c|}
\hline Test Dimensions & Correlation Coefficient \\
\hline \hline Receptive aspect & $0.973^{* *}$ \\
\hline Productive aspect & $0.879 * *$ \\
\hline
\end{tabular}

*Correlation is significant at the 0.05 level

**Correlation is significant at the 0.01 level

Table (2) shows that the correlation coefficient between the total score of each main aspect (receptive and productive) and the total score of the test are significant at 0.01 or 0.05 levels so it can be said that the test is valid.

For reliability purposes, two methods were used: test-retest method and Alpha Cronbach method. With regard to test-retest method, the EFL vocabulary test (receptive and productive)was administrated to a group of $2^{\text {nd }}$ year preparatory school pupils at Ahmed Zweil Official Language School, Benha, Alqalubia Governorate $(n=25)$ other than the sample of the study at the beginning of the first term of the academic year 2018/2019. Then, it was administrated again after two weeks to the same group. In order to calculate the reliability of the test, software of SPSS (v.18) was used. The Pearson correlation coefficient between the two administrations was (0.924) which is significant at the 0.01 level.

Table (3) Pearson correlations between each aspect (receptive aspects and productive aspects) and the total score of the test

\begin{tabular}{|l|c|}
\hline \multicolumn{1}{|c|}{ Aspects } & Correlation coefficient \\
\hline \hline Receptive aspects & $0.653^{* *}$ \\
\hline $\begin{array}{l}\text { Productive } \\
\text { Aspects }\end{array}$ & $0.819 * *$ \\
\hline Total & $0.924 * *$ \\
\hline
\end{tabular}

**Correlation is significant at the 0.01 level

Table (3) shows that the correlation coefficients of the receptive aspects, productive aspects and the overall test between the two 
administrations were $(0.653),(0.819)$ and $(0.924)$ respectively. These values are significant at the 0.01 level.

Besides, Cronbach's Alpha reached (0.704). This means that the EFL vocabulary test (receptive and productive) is reliable.

\section{The Experimental Treatment}

The implementation of the program went through three phases: Preimplementation, implementation, and post implementation as follows:

\section{The First Phase: Pre-implementation}

Before implementing the program, the EFL vocabulary pre-test (receptive and productive) was administrated to the participants on $9^{\text {th }}$ October at the beginning of first term of the academic year2018-2019. Table (4) shows t-test between the mean scores of the experimental group and the control group in the pre-EFL vocabulary test (receptive and productive).

Table (4): t-test between the mean scores of the experimental group and the control group in the pre-EFL vocabulary test(receptive and productive)

\begin{tabular}{|c|c|c|c|c|c|c|c|c|}
\hline The test & $\mathrm{N}$ & Group & Mean & $\begin{array}{c}\text { Std. } \\
\text { Deviation }\end{array}$ & $\begin{array}{c}\text { T- } \\
\text { Value }\end{array}$ & D.F & Sig & $\begin{array}{c}\text { A } \\
\text { Sig. }\end{array}$ \\
\hline \multirow{2}{*}{$\begin{array}{l}\text { Receptive } \\
\text { Aspect }\end{array}$} & 30 & Experimental & 13.1000 & 3.34612 & \multirow{2}{*}{0.308} & \multirow[t]{2}{*}{58} & \multirow{2}{*}{$\begin{array}{c}\text { Non- } \\
\text { significant }\end{array}$} & \multirow{2}{*}{0.759} \\
\hline & 30 & Control & 12.8333 & 3.36394 & & & & \\
\hline \multirow{2}{*}{$\begin{array}{l}\text { Productive } \\
\text { Aspect }\end{array}$} & 30 & Experimental & 10.4500 & 2.53714 & \multirow[b]{2}{*}{0.021} & \multirow[b]{2}{*}{58} & \multirow[b]{2}{*}{$\begin{array}{c}\text { Non- } \\
\text { significant }\end{array}$} & \multirow[b]{2}{*}{0.983} \\
\hline & 30 & Control & 10.4333 & 3.51532 & & & & \\
\hline \multirow{2}{*}{ Total } & 30 & Experimental & 23.5500 & 5.46990 & \multirow{2}{*}{0.198} & \multirow{2}{*}{58} & \multirow{2}{*}{$\begin{array}{c}\text { Non- } \\
\text { significant }\end{array}$} & \multirow{2}{*}{0.844} \\
\hline & & Control & 23.2667 & 5.63813 & & & & \\
\hline
\end{tabular}

Table (4) shows that t-values of the EFL vocabulary pre-test (receptive and productive) was not significant at the 0.05 level. This shows that both the experimental and the control groups were homogenous in main aspects of the EFL vocabulary test (receptive and productive).

\section{The Second Phase: Implementation of the Program}

The implementation started at the beginning of the first term of the academic year 2018-2019 on Thursday 11 of October and lasted for ten 
weeks. The experimental group $(n=30)$ was taught by the researcher using the program based on the integration between the incidental and intentional learning. Thirty-One sessions were taught; each session lasted for 90 minutes to 120 minutes. At the beginning of the first session, the researcher told the pupils about the objectives of the program and the importance of developing receptive and productive vocabulary learning for them. Then, the researcher introduced the rest of the sessions of the program through which pupils practiced the EFL receptive and productive vocabulary learning.

At the beginning of the incidental sessions, the researcher presented the objectives and asked the pupils to read the stories independently, highlight the unknown words and try to make a correct guess for them. She facilitated pupils' understanding of the stories by making a discussion and she took notes of the correct guess in the correct guessing rate sheets. The researcher applied the program's principles by asking pupils to practice the activities such as retelling the stories and playing roles of the story characters.

However, at the beginning of the intentional sessions, the researcher provided the pupils with warm up activities before reading the text. Then she read the text and at the end, she asked pupils to answer the questions in the activity.

At the beginning of the integration sessions and enrichment integration activities, she warmed the pupils by asking some questions. Then, she asked pupils to read the texts and try to make a guess for the unknown words and if they couldn't make a guess, they used the dictionaries or she gave them the right meaning. At the end of the session she helped them to practice the activities.

\section{The third phase: Post-Implementation}

The researcher administrated the EFL vocabulary posttest(receptive and productive) to the study participants on Sunday, December, $23^{\text {rd }}, 2018$ to identify the effectiveness of using the programin 
developing EFL receptive and productive vocabulary Learning. The data were statistically analyzed and interpreted.

\section{Findings of the study:}

The findings of the present study are presented in the light of the hypotheses of the study. Data of the present study was statistically treated using the Statistical Package for Social Sciences (SPSS) version 18.

\section{Findings of the First Hypothesis}

The first hypothesis states that "there is a statistically significant difference between the mean scores of the experimental and the control groups on the posttest of the EFL receptive vocabulary aspects in favor of the experimental group".

For verifying this hypothesis, independent samples t-test was used. Table (5) presents the pupils' mean scores, standard deviations, t-value, degree of freedom (DF), and the significance level of the study sample in post assessment of receptive vocabulary aspect.

Table (5): t-test between the mean scores between the experimental and control group of the EFL receptive vocabulary aspects

\begin{tabular}{|c|c|c|c|c|c|c|c|c|}
\hline Aspects & Group & $\mathbf{N}$ & Mean & $\begin{array}{c}\text { Std. } \\
\text { Deviation }\end{array}$ & \begin{tabular}{c|}
$t-$ \\
Value \\
\end{tabular} & D.F & Sig. & $\eta 2$ \\
\hline \multirow{2}{*}{$\begin{array}{c}\text { EFL } \\
\text { receptive } \\
\text { vocabulary } \\
\text { aspect }\end{array}$} & Control & 30 & 13.3333 & 3.79958 & \multirow{2}{*}{15.977} & \multirow{2}{*}{58} & \multirow{2}{*}{0.01} & \multirow{2}{*}{0.90} \\
\hline & Experimental & 30 & 27.7667 & 3.16972 & & & & \\
\hline
\end{tabular}

Table (5) shows that there is a statistically significant difference between the mean scores of the experimental and the control groups in the post assessment of receptive vocabulary aspect in favor of the experimental group, where the t-value is 15.977 which is significant at 0.01 . In addition, table (5) shows that $\eta 2$ is 0.90 which shows high effect size. Thus, the second hypothesis was confirmed. 


\section{Findings of the Second Hypothesis}

The second hypothesis states that "there is a statistically significant difference between the mean scores of the experimental and the control groups in the posttest of the EFL productive vocabulary aspects in favor of the experimental group."

For verifying this hypothesis, independent samples t-test was used. Table (6) presents the pupils' mean scores, standard deviations, t-value, degree of freedom (DF), and the significance level of the study sample in post assessment of productive vocabulary aspect.

Table (6): t-test between the mean scores of the experimental and control group in the posttest of the EFL productive vocabulary aspect

\begin{tabular}{|c|c|c|c|c|c|c|c|c|}
\hline Aspects & Group & $\mathbf{N}$ & Mean & $\begin{array}{c}\text { Std. } \\
\text { Deviation }\end{array}$ & t- Value & D.F & Sig. & $\eta 2$ \\
\hline \hline $\begin{array}{c}\text { EFL } \\
\text { productive } \\
\text { vocabulary } \\
\text { aspect }\end{array}$ & Control & 30 & 10.3167 & 3.37162 & & & & \\
\cline { 2 - 8 } & Experimental & 30 & 27.8333 & 4.18841 & 17.844 & 58 & 0.01 & 0.91 \\
\hline
\end{tabular}

Table (6) shows that there is a statistically significant difference between the mean scores of the experimental and the control groups in the post assessment in productive vocabulary aspects in favor of the experimental group, where the t-value is 17.844 which is significant at 0.01 . In addition, table (6) shows that $\eta 2$ is 0.91 which shows high effect size. Thus, the second hypothesis was accepted.

\section{Discussion and Interpretations of the Results}

This part is concerned with the interpretation and discussion of the previously mentioned findings. The findings are interpreted and discussed in the light of study hypotheses.

It is clear that the experimental group outperformed the control group in the posttest of the EFL receptive and productive vocabulary aspects. This development could be attributed to the usage of the balanced program that involved both incidental and intentional learning 
strategies such as guessing from context, possible sentences, semantic mapping, subjective and contextual redefinition strategies. These strategies provided learners with various activities and tasks which helped learners to develop their receptive and productive vocabulary aspects. This result is consistent with Nation (2000), Schmitt (2008), Yali (2010), Alemi and Tayebi (2011), Choo and Lin (2012), AlDarayseh (2014) and Nezhad, Moghali and Soor (2015).

The researcher exposed learners to a variety of texts, fiction and non-fiction, which increased the amount of engagement learners had with lexical items. The more cognitive energy a learner expands when manipulating and thinking about a word, the more likely he/she will be able to use and recall it later. This involvement is based on some factors which are need, search and evaluate in the tasks.

The researcher used extensive reading plus explicit exercise. Learners in the extensive reading (incidental sessions) learned some words that often stay at the recognition level, by contrast, the words learned in the reading plus explicit instruction (integration sessions) tended to stay at the productive level. Pupils who had practiced the words in a series of explicit activities could effectively manipulate them putting which put the target words into use correctly and appropriately in a written test. The reason lies in the reader's focus. In the extensive sessions (incidental learning), the learners focused on the meaning of a word and ignored the form of a word. However, recognizing the word meaning in the context is only one aspect of word knowledge. Knowing a word involves many other aspects such as learning the grammatical patterns and collocations. It also includes learning how to use it in suitable situations and using the word to stand for the meaning it presents and being able to think of suitable situations for the word. Thus, the program developed the pupils' vocabulary knowledge which is consistent with other researchers such as Nation (2000), Schmitt (2010) and Yanmei (2013). 
Moreover, pupils were exposed to authentic stories in the program so they picked up much vocabulary. The learners selected the stories themselves which motivated them to involve in learning for a period of time. The authentic stories helped learners to develop their receptive and productive vocabulary knowledge. This result is consistent with Sanchez and Schmitt (2010). In addition, the quality of the texts had a great influence on the pupils' vocabulary learning which is consistent with Webb (2008).

Pupils in the program read in different ways as they read extensively and intensively. The researcher used extensive reading in the incidental and integration sessions to increase the pupils' motivation and help them to be independent learners. She used intensive reading in the intentional sessions which exposed them to various types of activities such as making semantic maps. These activities helped them to manipulate the words effectively and use it correctly. This is consistent with other researchers such as Ahmadi (2017) and Jiren and Jianying (2018).

Concerning the receptive vocabulary aspect, the experimental group outperformed the control group in the posttest. This development could be attributed to various factors. The researcher used different strategies as she used guessing from context strategy that helped learners to recognize the written form and meaning of the word. This result is consistent with Hulstijn (2001).

Moreover, she used mnemonic strategy which helped learners to connect between new word and familiar one through visual or auditory cues and to match the form of the word with its meaning. This strategy also helped learners to remember and recall new words. This is consistent with other researchers such as Nemati (2009), Al-Zahrani (2011), Bakken (2011), Sozler (2012) and Khalafi and Oroji (2016).

The researcher also used word formation strategy in the intentional and integration sessions which helped learners to discriminate word formation patterns and distinguish the different lexical forms of a word. Thus, the word formation strategy developed pupils' vocabulary 
receptive aspects. This is consistent with the findings of Sadeghi et al. (2011). In addition, learners read for meaning in the extensive reading which helped them to develop their vocabulary receptive aspect. This is consistent with Nation (2000).

It is clear that the experimental group achieved more development than the control group in the posttest of the EFL productive vocabulary aspect. This development could be attributed to various factors. The researcher used different strategies in the program as she used semantic mapping strategy which helped learners to produce words associated with the meaning of the concept, produce words in meaningful groups and produce words that are used together. The result is consistent with other studies such as Abdelrahman (2013) and Dilek and Yuruk (2013). The program also included word formation strategy which helped learners to produce the word using the right word parts in their appropriate forms, use different word derivations and compounding. This strategy helped learners to develop their productive vocabulary aspect which is consistent with Scott (2002).

The researcher also used a variety of activities in the program such as making decisions, discussions and role play which encouraged re-use of the unknown vocabulary. She also used retelling activity which enhanced productive retrieval of vocabulary and ideal generative use of it. She also gave pupils' fifteen enrichment integration sessions which included varieties of independent activities that developed pupils' productive vocabulary aspect. Thus, the program improved pupils' productive vocabulary aspect that is consistent with Nation (2000).

\section{Definition of terms}

\section{EFL Vocabulary learning}

Schmitt $(2010,27)$ defined vocabulary learning as the means by which a learner comes to know a word and possess a general understanding of at least one basic meaning of a word in a particular 
context. The process of learning vocabulary includes exposure to new words through a variety of contexts.

Vasiljevic (2010, 200) also referred to vocabulary learning as a learning process during which individual words gradually move from a status of being unknown to being partially known and eventually integrated into the mental lexicon.

\section{Receptive vocabulary learning:}

Nation (2000, 37) defined receptive vocabulary learningas "the ability to comprehend a word's meaning when one hears or sees its form".

\section{Productive vocabulary learning:}

Sok $(2017,18)$ referred to productive vocabulary learning as "ability to produce a word's form and meaning to express oneself in speech or writing".

\section{Incidental learning:}

Schmitt $(2010,29)$ referred to incidental learning approach as "a byproduct of language usage without the intended purposes of learning a particular linguistic feature. An example is any vocabulary learned while reading a novel simply for pleasure, with no stated goal of learning new lexical item".

It is learning situation where learners are typically required to perform a task involving the processing of some information without being told in advance that they will be tested afterwards on their recall of that information. Learners don't work without attention to the learned words but they attend to learn words without intention to remember them later (Beltran, Contesse \& Lopez, 2010).

\section{Intentional Learning}

Richards and Schmidt (2000, 252) defined intentional learning as learning by following a deliberate program of study to enhance vocabulary.

Intentional learning is also defined as vocabulary learning approach where words are explicitly taught and intentionally focused 
upon by the learner through learning strategies such as mnemonic and word formation strategies. Learners' attention is explicitly focused on learning vocabulary (Schmitt, 2010, 33).

\section{Integrating Incidental and Intentional Learning}

Integrating Incidental and Intentional learning can be operationally defined as the learning in which second year official language preparatory school pupils learn vocabulary aspects both implicitly and explicitly through reading authentic stories for pleasure and meaning, through engaging in communicative activities and through intentional vocabulary strategies such as word formation, monomaniac and semantic map strategies.

\section{Recommendations of the study}

Based on the findings of the study, the following recommendations are suggested:

- Vocabulary learning (receptive and productive) learning should be given sufficient time in the English courses for official language preparatory school pupils.

- The balanced program based on integrating incidental and intentional learning should be implemented in teaching EFL vocabulary to pupils at the official language preparatory stage pupils.

- Teachers should train pupils on the use of different vocabulary learning strategies.

- Teachers should provide pupils with different types of texts (fiction and nonfiction), not only texts they study in the curriculum.

- Teachers should help pupils to read extensively.

- Teacher should use various communicative activities such as discussion, role play and retelling / rewriting the stories in the classroom. 
- Teaching should be turned from being teacher-centered to learner-centered in which learners become more involved in and be independent learners.

- Official language preparatory school pupils should be given more positive feedback about their progress in learning vocabulary aspects (receptive and productive).

- Teachers should provide pupils with enrichment independent integration activities in the program to enhance pupils' vocabulary learning (receptive and productive).

\section{Suggestions for further Research}

The results of the present study pointed out the need for conducting the following research:

- Investigating the effect of integrating incidental and intentional learning on developing EFL receptive and productive vocabulary learning among learners at other educational levels: secondary and college.

- Identifying the effectiveness of the program based on integrating incidental and intentional learning on developing other skills such as reading fluency and speaking.

- Investigating the effect of context clues and semantic mapping strategies on developing EFL receptive and productive vocabulary learning among official language learners at different educational levels.

- Investigating the effectiveness of vocabulary strategies training program on developing EFL receptive and productive vocabulary learning among advanced learners. 


\section{References}

Abdelrahman, O. (2013). The effect of teaching vocabulary through semantic mapping on EFL learners' awareness of vocabulary knowledge at Al Imam Mohamed Ibn Saud Islamic University. International Interdisciplinary Journal of Education, 2(7), 722-731.

Ahmadi, S. (2017). The impact of incidental and intentional L2 vocabulary learning on depth and breadth dimensions of vocabulary knowledge. The Buckingham Journal of Language and Linguistics, 10, 1-17.

Al-Dagel, S. R. (2009). EFL vocabulary learning and teaching problems and techniques. Faculty of Education Journal, Ain Shams University, 3(33), 1-28.

Al-Darayseh, A. (2014). The impact of using explicit/implicit vocabulary teaching strategies on improving students' vocabulary and reading comprehension. Theory and Practice in Language Studies, 4(6), 1109-1118.doi: 10.4304/tpls.4.6.1109-1118.

Alemi, M. \& Tayebi, A. (2011).The influence of incidental and intentional vocabulary acquisition and vocabulary strategy use on learning L2 vocabulary. Journal of Language Teaching and Research, 2(1),81-98. doi: 10.4304/jltr.2.1.81-98.

Ali, H. (2014). Effects of digital storytelling on developing English vocabulary of preparatory school students. Unpublished M. A. Thesis, Faculty of Education at Qena, South Valley University.

Al-Zahrani, M. (2011).The effectiveness of keyword based instruction in enhancing English vocabulary achievement and retention of intermediate stage pupils with different working memory capacities. M.Ed. Thesis, Faculty of Education, Taif University.

Bakken, J. (2011). Mnemonic strategies success for the young-adult learner. The human Resource and Adult Learner,7(2), 79-82. 
Barker, L. (2012). Defining the parameters of incidental learning on a serial reaction time (SRT) task: Do conscious rules apply? Journal of Brain Sciences, 2, 769-789.

Beltran, R., Contesse, C. \& Lopez, M. (2010).Insights into non-native vocabulary teaching and learning. In R. Beltran, C. Contesse \&M. Lopez (Eds.), Insights into non-native vocabulary teaching and learning (pp. 1-22). Ireland: David Singleton.

Bilen, D. \&Tavil, Z. (2015).The effect of cooperative learning strategies on vocabulary skills of $4^{\text {th }}$ grade students. Journal of Education and Training Studies, 3(6), 151-165. doi: 10.11114/jets.v3i6.1062.

Choo, L., Lin, D. \& Pandian, A. (2012). Language learning approaches: A review of research on explicit and implicit learning in vocabulary acquisition. Social and Behavioral Sciences, 55, 852860. doi: 10.1016/j.sbspro.2012.09572.

Cohen, A., \& Aphek, E. (1981). Easifying Second Language learning. Studies in Second Language Acquisition Journal, 3(2), 221-236. https://doi.org/10.1017/S0272263100004198.

Conderman, G., Hedin, L., \& Bresnahan, V. (2013).Strategy instruction for middle and secondary students with mild disabilities. New York: Corwin.

Dilek, Y. \&Yuruk, N. (2013).Using semantic mapping techniques in vocabulary teaching at pre-intermediate level. Journal of Social and Behavioral Sciences, 7, 1531-1544. doi: 10.1016/j.sbspro.2013.01.221.

El-Garawany, M. (2010).The effects of Repeated Reading Strategies on Developing Oral Reading Fluency and Reading Comprehension among EFL Prospective Teachers. Unpublished M.A. thesis, Faculty of Education, Minufiya University. 
El-Garhy, N. (2013).The effect of some strategies based on descriptive writing on enhancing EFL preparatory school students' vocabulary retention and sentence structure. Unpublished M.Ed. Thesis, Faculty of Education, Zagazig University.

EL-Khodary, A. (2007). The effectiveness of a proposed non-graded activities based program in developing English vocabulary for primary school pupils. Journal of Reading and Knowledge, 70, 1-24.

Ellis, R. (2008). Implicit and explicit knowledge about language. In R. Ellis, S. Loewen, C. Elder, R. Erlam, J. Philip \& H. Reinders (Eds.), Implicit and explicit knowledge in Second Language learning, testing and teaching (pp.1-100). UK: Short Run Press Ltd.

Gurock, F. (2016). Learning vocabulary through text messages: Help or distraction? Social and Behavioral Sciences Journal, 23(2), 623630. https://doi.org/10.1016/j.sbspro.2016.10.086..

Hamed, D. (2009).The difficulties and semantic elements in teaching vocabulary items. Tikrit University Journal for Humanities, 16, (11), 1-15.

Huckin, T. \& Coady, J. (1999). Incidental vocabulary acquisition in a Second Language: A review. Studies of Second Language Acquisition Journal, 21, 181-193.

Hulstijn, J.H. (2001). Intentional and incidental Second Language vocabulary learning: A reappraisal of elaboration, rehearsal, and automaticity. In P. Robinson (Ed.), Cognition and Second Language instruction (PP. 258-286). New York: Cambridge University Press.

Hulstijn, J.H. (2003). Incidental and intentional learning. In C.J. Doughty \& M.H. Long (Eds.), The hand book of Second Language acquisition (PP. 349-381). UK: Black Well.

Jiren, L. \& Jianying, Z. (2018). The effect of extensive reading on English vocabulary learning: A meta-analysis. English Language Teaching Journal, 11(6), 1-15.http://doi:org/10.5539/elt.v11n6p1. 
Kerka, S. (2000). Incidental learning: Trends and issues alert. Retrieved fromhttp://ericacve.org/tia.asp.

Khalafi, Z. \&Oroji, M. (2016). The impact of using keyword method on vocabulary learning and retention: A case of Iranian intermediate EFL learners. International Journal of Language and Linguistics, 4(1), 9-13. doi: 10.11648/j.ij11.20160401.12.

Khodary, A. (2007). The effectiveness of a proposed non-graded activity based program in developing English vocabulary for primary school pupils. Reading and Knowledge Journal,70, 1-24.

Nation, I. (1994). New Ways in teaching vocabulary. Virginia TESOL. Eric, ISBN: ISBN-0-939791-51-X.

Nation, I. (2013). Learning vocabulary in another language. Cambridge: Cambridge University Press.

Nation, I. S. P. (2000).Learning vocabulary in another language. Cambridge: Cambridge University Press.

Nemati, A. (2009). Memory vocabulary learning strategies and longterm retention. International Journal of Vocational and Technical Education, 1(2), 14-24.

Nezhad, A., Moghali, M., \& Soori, A. (2015). Explicit and implicit teaching.Asian Journal of Education and E-Learning, 3(1), 18-25.

Ramadan, H. (2016). A suggested integrative reading strategy to develop EFL prep school students' oral reading fluency and vocabulary acquisition, Unpublished M.A. thesis, Faculty of Education, Zagazig University.

Richards, J. \& Schmidt, R. (2002). Longman dictionary of language teaching and applied linguistics. Malaysia: Pearson Education.

Sadeghi, M., Nasrollahi, M., Mazandarani, O. \& Mesagar, M. (2011).Teaching vocabulary through word formation strategies among Iranian intermediate EFL students. International Conference on Languages, Literature and Linguistics, 26, 556-561. 
Sanad, H. (2015). A program based on the lexical approach to develop English as Foreign Language (EFL) vocabulary and reading comprehension skills among secondary students. Unpublished $\mathrm{Ph}$.D. thesis, College of Education, Suez Canal University.

Sanchez, A.\& Schmitt, N. (2010). Incidental vocabulary acquisition from an authentic novel: Do things fall apart? Reading in A Foreign Language Journal, 22(1), 31-55.

Schmitt, N. (2007). Current perspectives on vocabulary teaching and learning.In J. Cummins \& C. Davison (Eds.), International handbook of English Language teaching (pp. 827-841). New York: Springer Science and Business Media.

Schmitt, N. (2008). Review article: Instructed second vocabulary learning. Language Teaching Research Journal,12, 329-363.doi: 10.1177/136218808089921.

Schmitt, N. (2010). Key issues in teaching and learning vocabulary. In R. Beltran, C. Contesse \&M. Lopez (Eds.), Insights into non-native vocabulary teaching and learning (pp. 28-44). Ireland: David Singleton.

Schmitt, N. (2010). Researching Vocabulary: A vocabulary research manual.UK: Palgrave Macmillan.

Scott, H. (2002). How to teach vocabulary. Cambridge: Cambridge University Press.

Scott, J. (2012). A rational for an integration of explicit and incidental learning approaches to vocabulary acquisition at a postintermediate level .Retrieved from: http://www.developteachers.com/ vocab. Acquisition 3_ scotthtm.

Sok, S. (2017).Incidental and intentional L2 vocabulary acquisition. Doctoral Dissertation. Retrieved from proQuest Digital Dissertation and Thesis.(UMI 10286504). 
Sokmen, A. (1997). Current trends in teaching Second Language vocabulary. In N. Schmitt, \& M. McCarthy (Eds.), Vocabulary: Description, acquisition and pedagogy,(PP.152-161). Cambridge: Cambridge University press.

Sozler, S. (2012).The effect of memory strategy training on vocabulary development of Austrian secondary school students.Social Behavioral Sciences Journal,46, 1348-1352. doi: 10.1016/j.sbspro.2012.300.

Sulayman, R. (2011). The effect of using pictorial story style on the acquisition of new English vocabulary by sixth primary pupils. Collage of Basic Education Researches Journal, 10(3), 656-690.

Vasiljevic, Z. (2010). Word associations as a vocabulary-learning strategy in advanced L2 reading class. In R. Beltran, C. Contesse \& M. Lopez (Eds.), Insights into non-native vocabulary teaching and learning (pp. 186-206). Ireland: David Singleton.

Webb, S. (2008). The effects of context on incidental vocabulary learning. Reading in A Foreign Language Journal, 20, 232-245.

Yali, G. (2010). L2 vocabulary acquisition through reading incidental learning and intentional learning.Journal of Applied Linguistics,33(1), 74-94.

Yanmei, L. (2013). Toward a comprehensive model of Foreign Language: To integrate instructed learning with incidental learning. Asian Social Science, 9(10), 142-150. doi: 10.55391ass.v9n10p142.

Zhong, H. (2016). The relationship between receptive and productive vocabulary knowledge: A perspective from vocabulary use in sentence writing. The Language Learning Journal,1(2), 1-17. doi:10.1080/09571736.2015.1127403. 